Check for updates

Cite this: RSC Adv., 2017, 7, 37765

\title{
Size-dependent optical and thermochromic properties of $\mathrm{Sm}_{3} \mathrm{Fe}_{5} \mathrm{O}_{12}$
}

\author{
Huanhuan Liu, $\uparrow^{\mathrm{a}}$ Long Yuan, (D) $\dagger^{\mathrm{ab}}$ Hui Qi, ${ }^{\mathrm{c}}$ Yanyan Du, ${ }^{\mathrm{d}}$ Shan Wang ${ }^{\mathrm{e}}$ \\ and Changmin $\mathrm{Hou}$ (D) *a
}

Reversible thermochromic inorganic materials of $\mathrm{Sm}_{3} \mathrm{Fe}_{5} \mathrm{O}_{12}$ with different particle sizes have been synthesized by a conventional high temperature solid state reaction method $(2.51 \mu \mathrm{m})$ and sol-gel method $(0.16 \mu \mathrm{m})$. The as-prepared samples were characterized by powder X-ray diffraction (XRD), scanning electron microscopy (SEM), infrared spectroscopy (IR), Raman, X-ray photoelectron spectroscopy (XPS) and UV-vis-NIR spectroscopy. The sizes of $\mathrm{Sm}_{3} \mathrm{Fe}_{5} \mathrm{O}_{12}$ particles have a significant difference effect on the color of pigments. The absorption peak shifts to lower wavelength with the increase of particle size. The bandgap and lattice parameter increase with the decrease in particle size. Thermochromism for $\mathrm{Sm}_{3} \mathrm{Fe}_{5} \mathrm{O}_{12}$ synthesized by the solid state reaction method showed a change in color from dark green to reddish brown and the samples synthesized by a sol-gel method changed from bright yellowish green to yellow. The cause of the thermochromism is the continuous red shift of ligand-metal charge transfer with the increase of temperature. This work suggests that the properties of thermochromic materials could be tuneable by particle size.

Received 23rd May 2017

Accepted 4th July 2017

DOI: $10.1039 / c 7 r a 05803 a$

rsc.li/rsc-advances
$\mathrm{Zn}_{3}\left(\mathrm{PO}_{4}\right)_{2}: \mathrm{Mn}_{2+}, \mathrm{CoCO}_{2}, \mathrm{NiC}_{2} \mathrm{O}_{4} \cdot{ }^{4,5}$ At present, the categories of reversible thermochromic inorganic materials are limited, mainly vanadium dioxide $\left(\mathrm{VO}_{2}\right)$ and tungsten- or molybdenumbased oxides. ${ }^{6-9}$ Therefore, the producing nontoxic and reversible inorganic thermochromic materials are pressing. Rare-earth iron garnet $\mathrm{Y}_{3} \mathrm{Fe}_{5} \mathrm{O}_{12}$ and $\mathrm{Sm}_{3} \mathrm{Fe}_{5} \mathrm{O}_{12}$ are reported to possess reversible thermochromic properties. ${ }^{\mathbf{1 0 1 1}}$ The rare-earth iron garnet $\left(\mathrm{RE}_{3} \mathrm{Fe}_{5} \mathrm{O}_{12}\right)$ not only has significant thermochromic behavior, but also has excellent physical properties, which can be widely used in microwave field. ${ }^{12,13}$ The rare-earth iron garnet $\left(\mathrm{RE}_{3} \mathrm{Fe}_{5} \mathrm{O}_{12}\right)$ belong to cubic crystallographic system with space group $I a \overline{3} d$, in which unit cell contains eight $\mathrm{RE}_{3} \mathrm{Fe}_{5} \mathrm{O}_{12}$ molecules and the crystal lattice contains three crystallographic sites, the tetrahedral site $24 \mathrm{~d}\left(\mathrm{Fe}^{2+}\right)$, the octahedral site $16 \mathrm{a}\left[\mathrm{Fe}^{3+}\right]$, the dodecahedral site $24 \mathrm{c}\left\{\mathrm{RE}^{3+}\right\} .{ }^{14}$ There is no effective close-packed structure in the garnet ferrite, which cannot be distorted to a lower symmetry and the stability of rare earth garnet ferrite decreases with the increase of the radius of rare earth ions. ${ }^{15}$ The $\mathrm{RE}_{3} \mathrm{Fe}_{5} \mathrm{O}_{12}$ with small radius of rare earth ions (Sm-Lu, and Y) can be prepared by solid state reaction, ${ }^{\mathbf{1 6 , 1 7}}$ while $\mathrm{RE}_{3} \mathrm{Fe}_{5} \mathrm{O}_{12}$ with large radius of rare earth ions ( $\mathrm{Pr}, \mathrm{Nd}$ ) only can be synthesized by mild hydrothermal method ${ }^{18}$ or low temperature liquid phase epitaxy technique. ${ }^{19}$

Size-dependent physicochemical properties have been investigated in many materials in the last two decades, such as magnetic, ${ }^{20,21}$ catalytic properties, ${ }^{22-24}$ gas sensing properties ${ }^{25}$ and optical properties. ${ }^{26}$ In addition, grain size has a very significant impact on color of the sample, for example, with the increase of the grain size, the color of the CdSe nanoparticles 
was deepened. ${ }^{27}$ Grain size govern the color of the substance originates in the variation of the bandgap and thereby give rise to absorption wavelength shift. ${ }^{28,29}$ Size-dependent thermochromism has been found in $\mathrm{CuO}$ quantum dots due to the tunable electron-phonon coupling with nanocrystal size evolution. ${ }^{30}$ However, there are few reports about the research of size-dependent thermochromism.

In previous work, we developed an in situ optical and structural characterization method for the studying of chemical pressure effect on thermochromic property of $\mathrm{Sm}_{3-x} \mathrm{Bi}_{x} \mathrm{Fe}_{5}$ $\mathrm{O}_{12} \cdot{ }^{31}$ In this paper, we report grain size-dependent properties of thermochromic material of $\mathrm{Sm}_{3} \mathrm{Fe}_{5} \mathrm{O}_{12} . \mathrm{Sm}_{3} \mathrm{Fe}_{5} \mathrm{O}_{12}$ with different particle size were synthesized by two synthetic methods. UV-vis absorption spectra showed that the bandgap increased with the decreasing particle size, and the color becomes lighter associated with blue shift. Reversible thermochromic between room temperature and $240{ }^{\circ} \mathrm{C}$ originates from red shift caused by a change in the ligand field around the chromophore. This indicates that the optical properties can be controlled and adjusted according to the required application by optimizing the particle size.

\section{Experimental}

\subsection{Preparation samples}

Pure $\mathrm{Sm}_{3} \mathrm{Fe}_{5} \mathrm{O}_{12}$ powders were prepared by traditional solidstate reaction method and sol-gel method respectively. Solidstate reaction: the stoichiometric amounts of high purity $\mathrm{Sm}_{2} \mathrm{O}_{3}$ and $\mathrm{Fe}_{2} \mathrm{O}_{3}$ were mixed evenly by grinding in agate mortar. Then, the blend was calcined at $1200{ }^{\circ} \mathrm{C}$ for $8 \mathrm{~h}$ and $1400{ }^{\circ} \mathrm{C}$ for $10 \mathrm{~h}$ with additional grinding after $8 \mathrm{~h}$. $\mathrm{Sm}_{3} \mathrm{Fe}_{5} \mathrm{O}_{12}$ were prepared after cooling. Samples were grinding for a long time until the sample has a tendency to stick to the mortar (about $30 \mathrm{~min}$ ), and particle size distribution, structure and optical spectroscopy properties were characterized after grinding. Sol-gel method: the stoichiometric amounts of $\mathrm{Fe}\left(\mathrm{NO}_{3}\right)_{3} \cdot 9 \mathrm{H}_{2} \mathrm{O}$ and citric acid were dissolved in aqueous solution and the required amounts $\mathrm{Sm}_{3}\left(\mathrm{NO}_{3}\right)_{3}$ was dissolved in another aqueous solution. The two solutions were mixed and began to stir for three days. The ammonia was added with drop by drop to above solution to adjust the value of $\mathrm{PH} \sim 7$. Three days later, the solution was heated from room temperature to $85^{\circ} \mathrm{C}$ at the rate of $10^{\circ} \mathrm{C} \mathrm{h}^{-1}$ to form the gel. The gel was dried at $110{ }^{\circ} \mathrm{C} \mathrm{h}^{-1}$ for $24 \mathrm{~h}$ and then treated at $950{ }^{\circ} \mathrm{C}$ for $12 \mathrm{~h}$ after being grinded.

\subsection{Characterization}

Powder X-ray diffraction patterns were recorded on a Rigaku D/ Max 2500V/Pc X-ray diffractometer with $\mathrm{Cu} \mathrm{K} \alpha$ radiation $(\lambda=$ $1.5418 \AA$ ) at $50 \mathrm{kV}, 200 \mathrm{~mA}$ and room temperature. The step scanning was set in an angle range of $10^{\circ} \leq 2 \theta \leq 80^{\circ}$ with increments of $0.02^{\circ}$ and a scanning speed of $3^{\circ} \mathrm{min}^{-1}$. Infrared spectra (IR) were performed in a range of $400-1500 \mathrm{~cm}^{-1}$ by Fourier transform infrared (FTIR) spectrometer. Raman spectra were characterized on Renishaw inVia Confocal Raman spectrometer with a $532 \mathrm{~nm}$ excited wavelength laser. The photographs of thermochromism at different temperature were obtained using camera. The CIE 1976 color parameters have been recorded by a NR200 type high-quality portable colorimeter (Shenzhen 3NH Technology Co., LTD) equipped with a standard D65 (Daylight, color temperature: $6504 \mathrm{~K}$ ) with a $10^{\circ}$ observer angle. Temperature-dependent ultraviolet-visible-near infrared (UV-vis-NIR) diffuse reflectance spectra were measured on Hitachi U-4100 UV-vis spectrometer equipped with temperature control accessory consists of a ceramic heating piece and temperature controlling device. Absorption coefficients $(\alpha / S)$ were calculated based on the reflectance by Kubelka-Munk transformation: $\alpha / S=(1-R)^{2} / 2 R$, where $R$ is the reflectance at the given wavelength, $\alpha$ is the UV-vis absorption coefficient, and $S$ is the scattering coefficient. The $S$ value is supposed to be particle size independent since grains size is larger than a few micrometers. X-ray photoelectron spectroscopy (XPS) measurements were performed by Thermo ESCALAB250 spectrometer with a monochromatic $\mathrm{AlK}_{\alpha}$ source.

\section{Results and discussion}

\subsection{SEM and particle size distribution}

Fig. 1 show SEM and particle size distribution graphs of the samples of $\mathrm{Sm}_{3} \mathrm{Fe}_{5} \mathrm{O}_{12}$ synthesized by two different methods. It is obviously observed that the particle size of $\mathrm{Sm}_{3} \mathrm{Fe}_{5} \mathrm{O}_{12}$ gained by solid state reaction is larger than that obtained by sol-gel method. The particle size were estimated using 100 distinct particles. From Fig. 1(c) it can be seen that the grain size of the samples is mainly distributed in $1.0-2.0 \mu \mathrm{m}$, the average grain size is $2.51 \mathrm{um}$ and the maximum is about $7.2 \mu \mathrm{m}$. Fig. 1(d) shows the average particle size of $\mathrm{Sm}_{3} \mathrm{Fe}_{5} \mathrm{O}_{12}$ samples gained by sol-gel method is $0.16 \mu \mathrm{m}$ and the particle size is mainly distributed in $0.12-0.2 \mu \mathrm{m}$, the maximum is about $0.3 \mu \mathrm{m}$. From
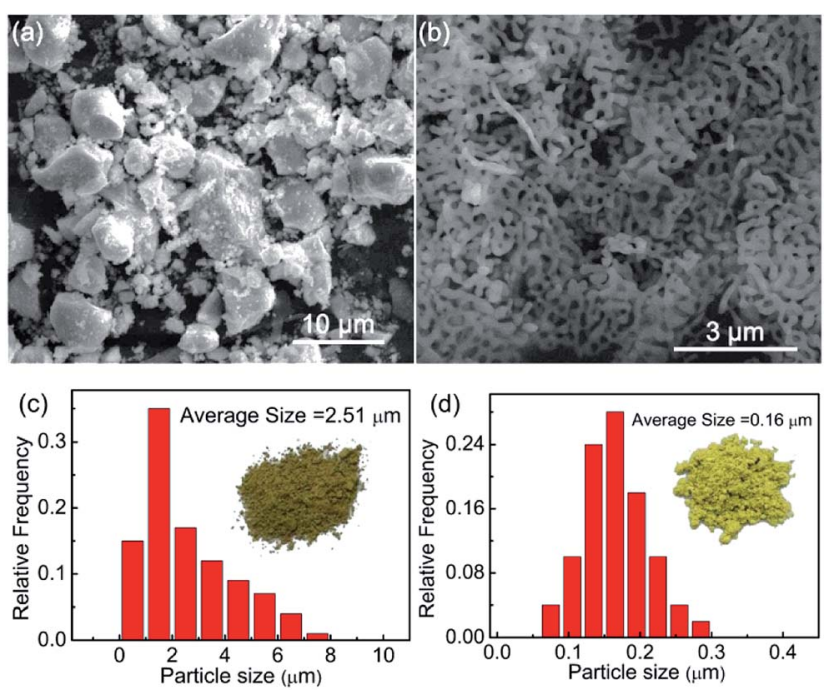

Fig. 1 (a) $\mathrm{SEM}$ graph of $\mathrm{Sm}_{3} \mathrm{Fe}_{5} \mathrm{O}_{12}$ samples synthesized by solid state reaction method; (b) SEM graph of $\mathrm{Sm}_{3} \mathrm{Fe}_{5} \mathrm{O}_{12}$ samples synthesized by sol-gel method; (c) particle size distribution of $\mathrm{Sm}_{3} \mathrm{Fe}_{5} \mathrm{O}_{12}$ samples synthesized by solid state reaction method; (d) particle size distribution of $\mathrm{Sm}_{3} \mathrm{Fe}_{5} \mathrm{O}_{12}$ samples synthesized by sol-gel method. The calculated number for each $\mathrm{Sm}_{3} \mathrm{Fe}_{5} \mathrm{O}_{12}$ sample is 200 . 
the graphs it can be observed that the samples synthesized by two different methods have a significant difference in color.

\subsection{Structural analysis}

Fig. 2 shows the refinement results of powder XRD patterns of the samples $\mathrm{Sm}_{3} \mathrm{Fe}_{5} \mathrm{O}_{12}$ with different particle size. The pattern is consistent with the standard spectrum and without any detectable impure phase. The results indicate the samples have only a single phase of the garnet structure. The refinement results show that the space groups of two samples were all $I a \overline{3} d$. The lattice constant of $\mathrm{Sm}_{3} \mathrm{Fe}_{5} \mathrm{O}_{12}$ with small particle size have increased, which is in agreement with the literatures. ${ }^{32-34}$ The cell parameter of $\mathrm{Sm}_{3} \mathrm{Fe}_{5} \mathrm{O}_{12}$ is $12.5350 \AA$ for the large sized samples, while expands to $12.5413 \AA$ for the smaller sized samples. HRTEM result of $\mathrm{Sm}_{3} \mathrm{Fe}_{5} \mathrm{O}_{12}$ synthesized by sol-gel method was shown in Fig. 3. The measured $d$-value of the observed plane lattice is $5.29 \AA$. According to the power XRD results, the distance along the $\{211\}$ plane is $5.12 \AA$, which indicates that the lattice of sol-gel method prepared $\mathrm{Sm}_{3} \mathrm{Fe}_{5} \mathrm{O}_{12}$ sample is expanded.
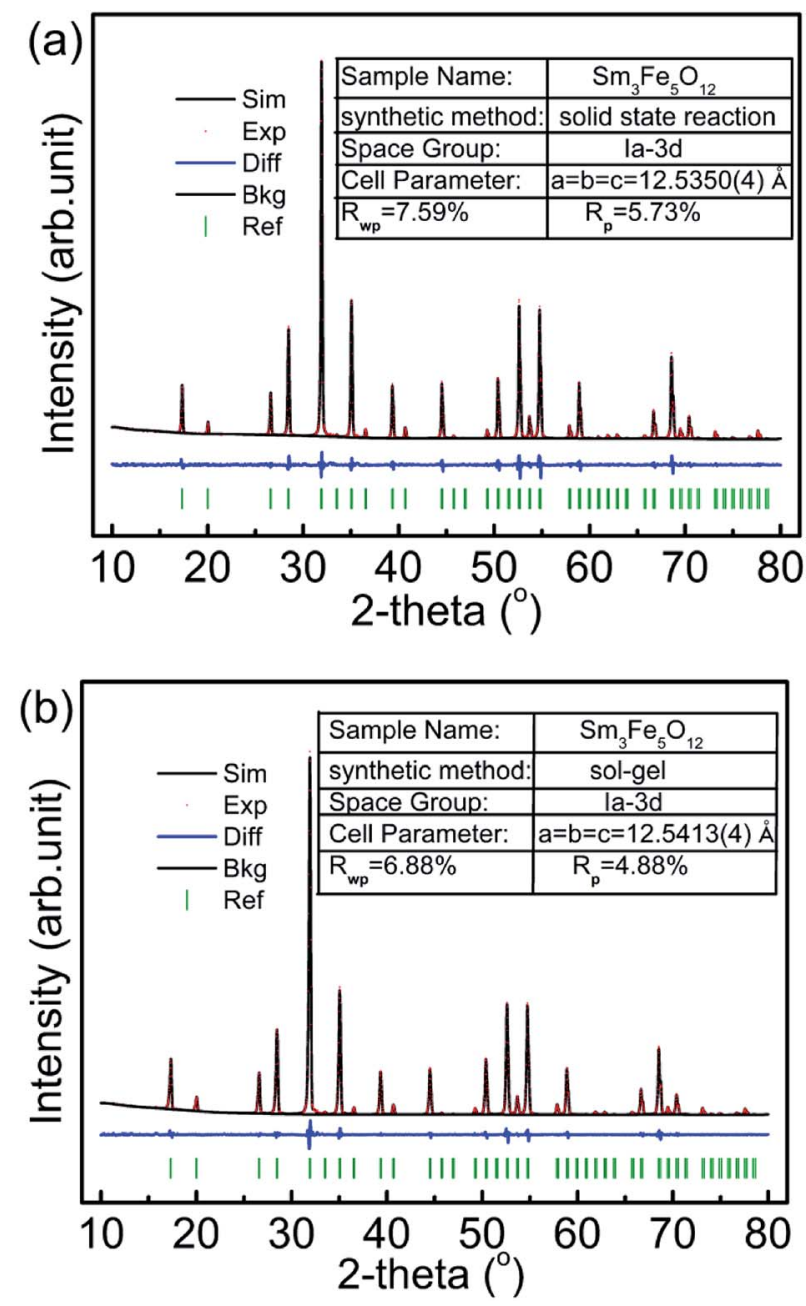

Fig. 2 Powder $\mathrm{X}$-ray diffraction patterns and Rietveld refinement results of $\mathrm{Sm}_{3} \mathrm{Fe}_{5} \mathrm{O}_{12}$ prepared by: (a) solid state reaction method and (b) sol-gel method.

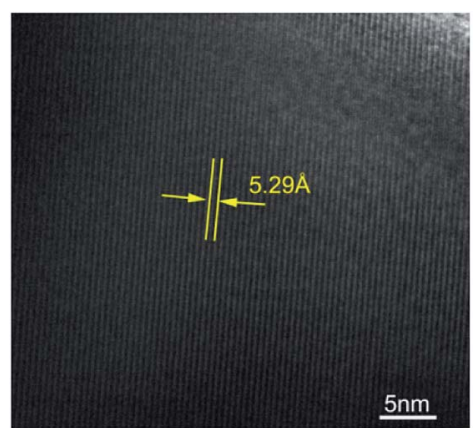

Fig. 3 HRTEM results of $\mathrm{Sm}_{3} \mathrm{Fe}_{5} \mathrm{O}_{12}$ synthesized by sol-gel method.

\subsection{FTIR spectra}

Fig. 4 presents the FTIR spectra of $\mathrm{Sm}_{3} \mathrm{Fe}_{5} \mathrm{O}_{12}$ with different particle size. From Fig. 4 it can be seen that there are three absorption peaks in the range of $500-650 \mathrm{~cm}^{-1}$ for each $\mathrm{Sm}_{3} \mathrm{Fe}_{5} \mathrm{O}_{12}$ samples, which were the characteristic peaks of the asymmetric stretching vibration of the group $\mathrm{Fe}-\mathrm{O}$ of tetrahedral. ${ }^{35}$ It is worthwhile to note that a red shift of the main peak from $584.9 \mathrm{~cm}^{-1}$ to $579.2 \mathrm{~cm}^{-1}$ with the decrease of the particle size is associated with the dilation of the $\mathrm{Fe}-\mathrm{O}$ bonds as the particle size decreases. ${ }^{36}$ In addition, the intensity of these absorption bands is strengthened with the decrease of particle size, which is related to the surface effect. ${ }^{37}$

\subsection{Raman microspectrometry}

Fig. 5 shows the Raman microspectrometry of $\mathrm{Sm}_{3} \mathrm{Fe}_{5} \mathrm{O}_{12}$ with different particle size. These two samples with different particle size show very similar spectral structure because they are isostructural. Though there are 98 vibration modes at the Brillouin zone center of rare earth iron garnet structure crystals, 55 $\left(5 \mathrm{~A}_{1 \mathrm{u}}+5 \mathrm{~A}_{2 \mathrm{~g}}+5 \mathrm{~A}_{2 \mathrm{u}}+10 \mathrm{E}_{\mathrm{u}}+14 \mathrm{~F}_{1 \mathrm{~g}}+16 \mathrm{~F}_{2 \mathrm{u}}\right)$ of them are silent and only $\mathrm{F}_{1 \mathrm{u}}$ is an acoustic mode. The all Raman active modes of the garnet are $3 \mathrm{~A}_{1 \mathrm{~g}}+8 \mathrm{E}_{\mathrm{g}}+14 \mathrm{~F}_{2 \mathrm{~g}}$, corresponding to internal modes, translational and rotatory modes. ${ }^{38}$ The distribution of all the observed Raman modes is shown in Fig. 5. The results were

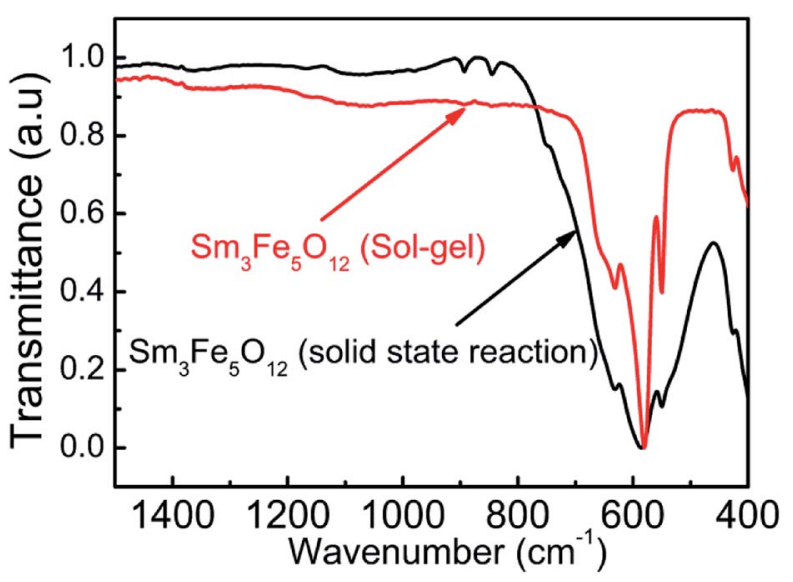

Fig. 4 The FTIR spectra of $\mathrm{Sm}_{3} \mathrm{Fe}_{5} \mathrm{O}_{12}$ synthesized by two different method in the range of $400-1500 \mathrm{~cm}^{-1}$. 


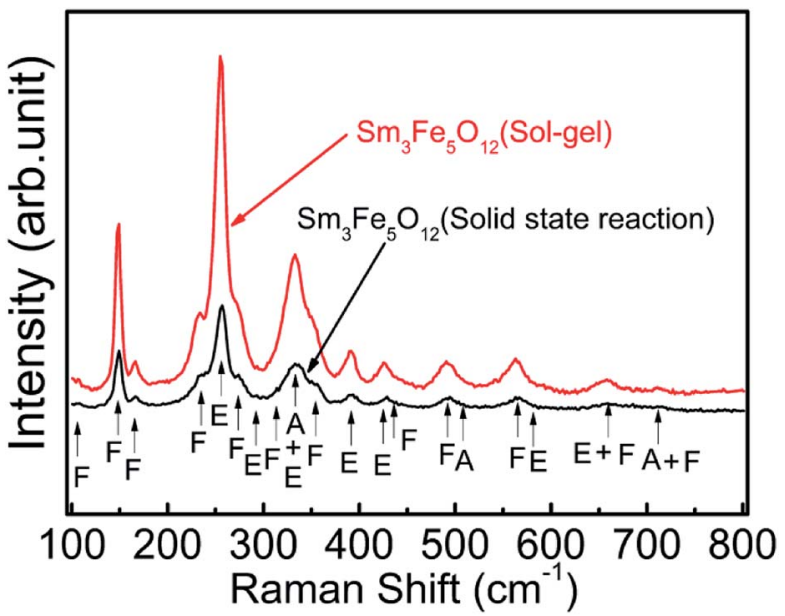

Fig. 5 Raman microspectrometry of $\mathrm{Sm}_{3} \mathrm{Fe}_{5} \mathrm{O}_{12}$ synthesized by two different methods in the range of $100-800 \mathrm{~cm}^{-1}$ at room temperature.

consistent with the $\mathrm{Sm}_{3} \mathrm{Fe}_{5} \mathrm{O}_{12}$ prepared by the hydrothermal method. ${ }^{39}$

\subsection{XPS spectra}

Chemical environment of $\mathrm{Fe}$ in different sized $\mathrm{Sm}_{3} \mathrm{Fe}_{5} \mathrm{O}_{12}$ samples were characterized by XPS of Fe $2 \mathrm{p}$ detailed spectra (Fig. 6). Asymmetric doublet with distinct satellite peaks of Fe $2 p$ orbitals are shown in both of the as-prepared two samples. Satellite peaks locate at higher binding energy than main peaks of c.a. $8 \mathrm{eV}$, which indicates the valence state of $\mathrm{Fe}$ is $+3 .{ }^{40}$ There are two crystallographic sites of $\mathrm{Fe}$ in $\mathrm{Sm}_{3} \mathrm{Fe}_{5} \mathrm{O}_{12}$ crystal lattice, i.e. tetragonal and octahedral sites, which could also be discriminated from XPS spectra. ${ }^{\mathbf{4 1 , 4 2}}$ The binding energy for tetrahedral site of $\mathrm{Fe}$ is 723.9 and $710.5 \mathrm{eV}$ for $\mathrm{Fe} 2 \mathrm{p}_{1 / 2}$ and $\mathrm{Fe}$ $2 \mathrm{p}_{3 / 2}$, respectively, while the binding energy for octahedral site of $\mathrm{Fe}$ is 727.2 and $712.7 \mathrm{eV}$ for $\mathrm{Fe} 2 \mathrm{p}_{1 / 2}$ and $\mathrm{Fe} 2 \mathrm{p}_{3 / 2}$, respectively. A comparison of two materials shows that the intensity of the peak of $\mathrm{Sm}_{3} \mathrm{Fe}_{5} \mathrm{O}_{12}$ synthesized by solid state reaction method is enhanced. It reveals that high temperature increases the degree of oxidation and the density of the samples. The high-density surface generates extra surface energy and promotes the oxidation reaction. ${ }^{43}$

\subsection{Optical properties and thermochromism}

Fig. 7 presents the room-temperature UV-vis-NIR diffuse reflectance and absorption (i.e., Kubelka-Munk transformed reflectance) spectra of $\mathrm{Sm}_{3} \mathrm{Fe}_{5} \mathrm{O}_{12}$ synthesized with different particle size in the range of 200-1200 nm. According to the optical measurements, the greenish color of $\mathrm{Sm}_{3} \mathrm{Fe}_{5} \mathrm{O}_{12}$ is assigned to a ligand-metal charge transfer in violet region with $\mathrm{Fe}^{3+} \mathrm{d}-\mathrm{d}$ transitions in the orange-red region. The band at $488 \mathrm{~nm}$ are the ligand-metal charge transfer from $2 \mathrm{p}$ orbitals of $\mathrm{O}^{2-}$ to the empty $3 \mathrm{~d}$ orbitals of $\mathrm{Fe}^{3+}\left(\mathrm{O}^{2-}+\mathrm{Fe}^{3+} \rightarrow \mathrm{O}^{-}+\mathrm{Fe}^{2+}\right)$, which is $485 \mathrm{~nm}$ for $\mathrm{Y}_{3} \mathrm{Fe}_{5} \mathrm{O}_{12} \cdot{ }^{10}$ The absorption bands around $610 \mathrm{~nm}$ and a shoulder at $700 \mathrm{~nm}$ correspond to the ${ }^{6} \mathrm{~A}_{1} \rightarrow{ }^{4} \mathrm{~T}_{1}$ transition of $\mathrm{Fe}^{3+}$ in octahedral site and the ${ }^{6} \mathrm{~A}_{1} \rightarrow{ }^{4} \mathrm{~T}_{1},{ }^{4} \mathrm{~T}_{2}$
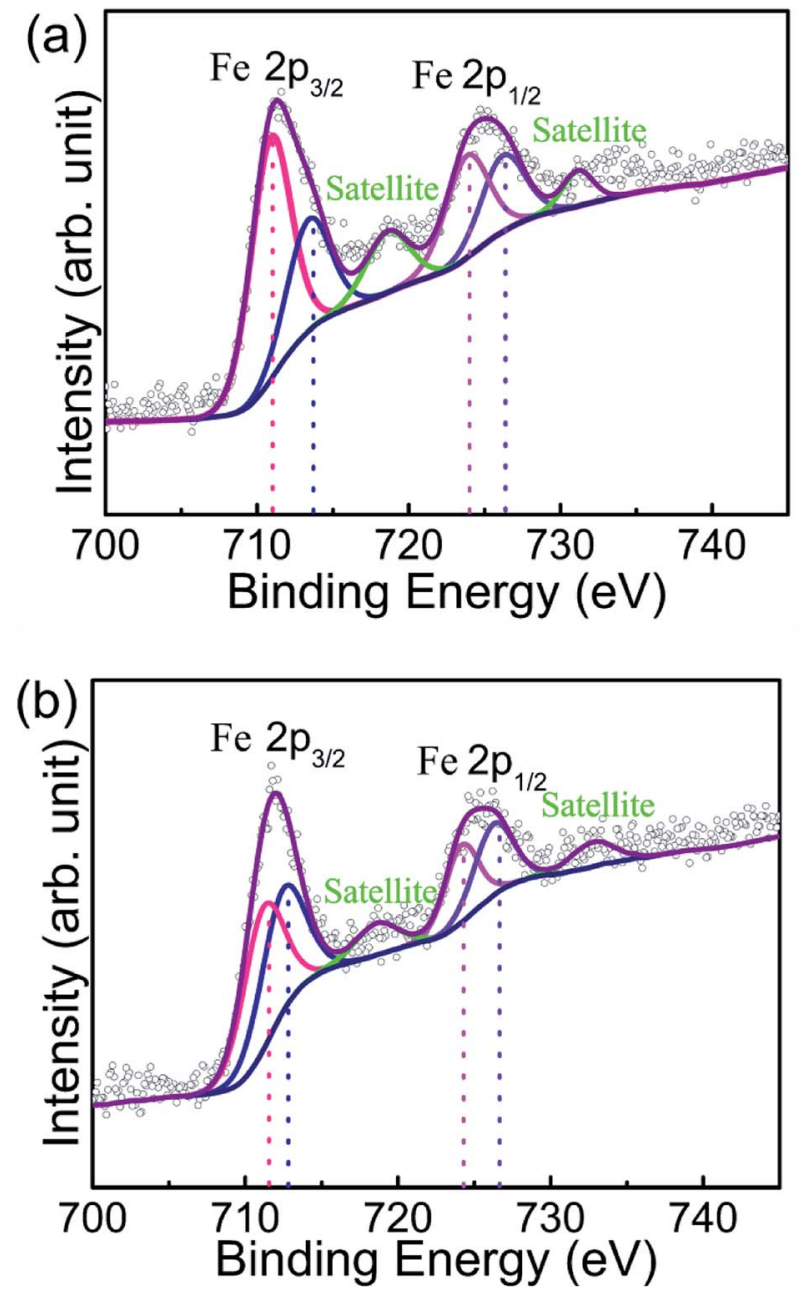

Fig. 6 XPS spectra of $\mathrm{SmFe}_{5} \mathrm{O}_{12}$ samples prepared by (a) solid state method and (b) sol-gel method, respectively. Binding energy curves of Fe $2 p_{1 / 2}$ (pink) and Fe $2 p_{3 / 2}$ (blue) are fits to the data (black open circles) using mixed Gaussian-Lorentzian functions, and red curves represent the sum of the peak fits. Satellite peaks are simulated with the same method marked with green lines. The Shirley method was used to subtract backgrounds.

transition of $\mathrm{Fe}^{3+}$ in tetrahedral site. Besides, band around $900 \mathrm{~nm}$ originate from the ${ }^{6} \mathrm{~A}_{1} \rightarrow{ }^{4} \mathrm{~T}_{1}$ transition of $\mathrm{Fe}^{3+}$ in octahedral site. It can be seen from Fig. 7 that a blue shift (from $488 \mathrm{~nm}$ to $450 \mathrm{~nm}$ ) of ligand-to-metal charge transfer with the decrease of the particle size while the position of $\mathrm{d}-\mathrm{d}$ transitions is almost unchanged. The insert graphs of Fig. 7 show that the bandgap of $\mathrm{Sm}_{3} \mathrm{Fe}_{5} \mathrm{O}_{12}$ with different particle size are $2.02 \mathrm{eV}$ (solid state reaction method) and $2.28 \mathrm{eV}$ (sol-gel method), respectively. The bandgap increases with the decrease of the particle size. The absorption intensity decreases with decreasing particle size due to enhancement of reflection strength associated with the reflection surface increase.

Fig. 8 show temperature dependent UV-vis absorption spectra and the evolution of bandgap for $\mathrm{Sm}_{3} \mathrm{Fe}_{5} \mathrm{O}_{12}$ with different particle size in the temperature range of $40-240{ }^{\circ} \mathrm{C}$. From Fig. 8 it can be seen that continuous red shift of the absorption bands at $488 \mathrm{~nm}$, whereas the positioning of $\mathrm{d}-\mathrm{d}$ 


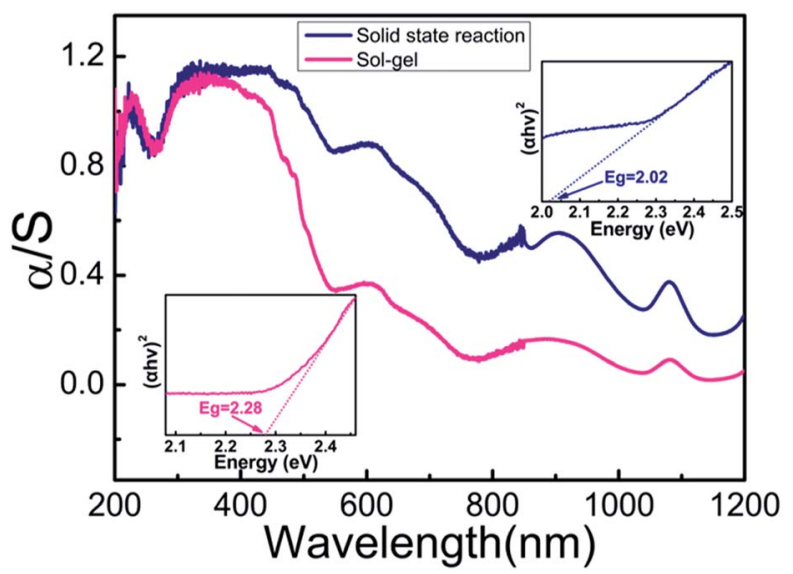

Fig. 7 Room temperature $\alpha / S$ spectrum (Kubelka-Munk transformation) and bandgap energy of $\mathrm{Sm}_{3} \mathrm{Fe}_{5} \mathrm{O}_{12}$ synthesized by two different methods.
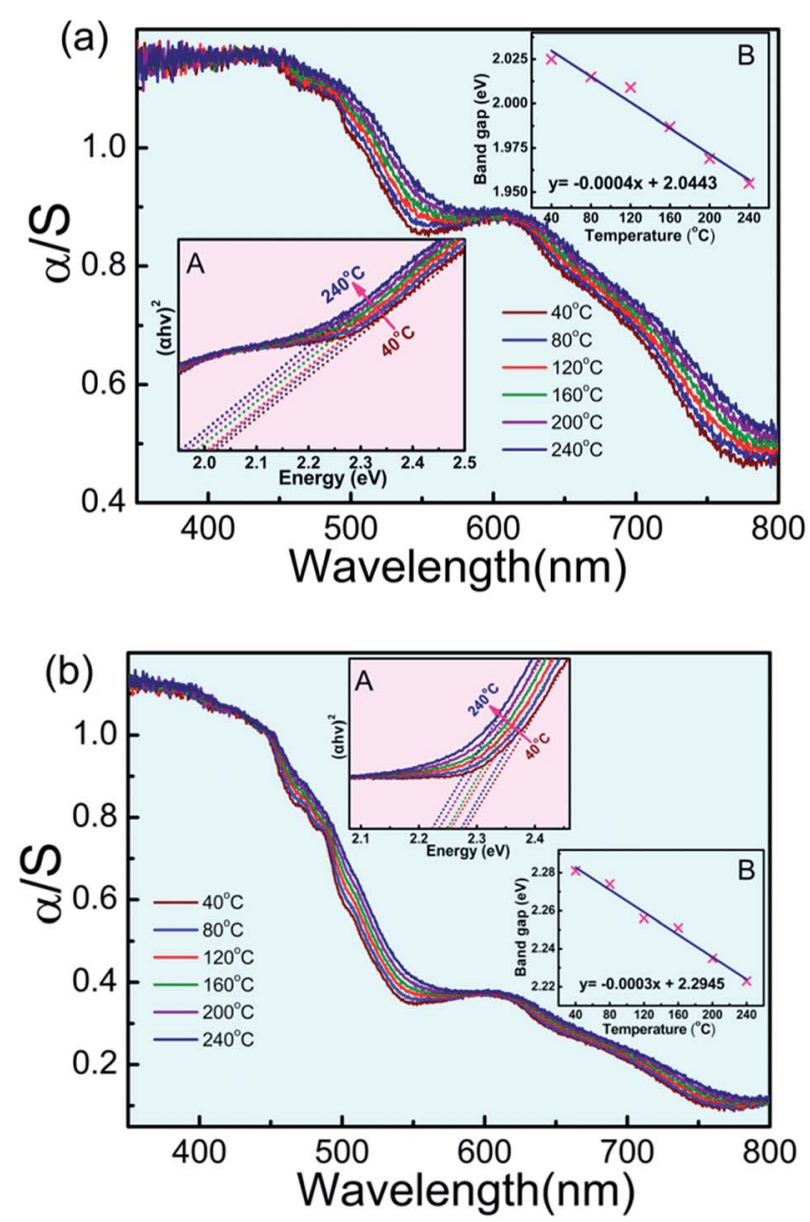

Fig. 8 Temperature dependent UV-vis spectra of $\mathrm{Sm}_{3} \mathrm{Fe}_{5} \mathrm{O}_{12}$ : (a) prepared by solid state method, (b) prepared by sol-gel method. Insets $A$ and $B$ show the Tauc plots of the UV-vis spectra and linear fitting of the energy bandgap dependent on temperature of $\mathrm{Sm}_{3} \mathrm{Fe}_{5} \mathrm{O}_{12}$ synthesized by two different method.

\begin{tabular}{|c|c|c|c|c|}
\hline & $\mathrm{Sm}_{3} \mathrm{Fe}_{5} \mathrm{O}_{12}$ solid state reaction method & \multicolumn{2}{|c|}{$\mathrm{Sm}_{3} \mathrm{Fe}_{5} \mathrm{O}_{12 \text { sol-gel }}$} \\
\hline Temperature & CIE-Lab parameter & Photograph & CIE-Lab parameter & Photograph \\
\hline \multirow{2}{*}{$40{ }^{\circ} \mathrm{C}$} & $\mathrm{L}^{*}=36.3$ & & $\mathrm{~L}^{*}=64.7$ & \\
& $\mathrm{a}^{*}=0.5$ & & $\mathrm{a}^{*}=-4.5$ & \\
& $\mathrm{~b}^{*}=27.2$ & & $\mathrm{~b}^{*}=48.8$ & \\
\hline \multirow{2}{*}{$80^{\circ} \mathrm{C}$} & $\mathrm{L}^{*}=34.4$ & & $\mathrm{~L}^{*}=63.6$ & \\
& $\mathrm{a}^{*}=-0.6$ & & $\mathrm{a}^{*}=3$ & \\
& $\mathrm{~b}^{*}=24.6$ & & $\mathrm{~b}^{*}=47.5$ & \\
\hline \multirow{2}{*}{$120^{\circ} \mathrm{C}$} & $\mathrm{L}^{*}=33.6$ & & $\mathrm{~L}^{*}=62.5$ & \\
& $\mathrm{a}^{*}=0.8$ & & $\mathrm{a}^{*}=-2.2$ & \\
& $\mathrm{~b}^{*}=23.6$ & & $\mathrm{~b}^{*}=45.9$ & \\
\hline \multirow{2}{*}{$160^{\circ} \mathrm{C}$} & $\mathrm{L}^{*}=26.5$ & & $\mathrm{~L}^{*}=59$ & \\
& $\mathrm{a}^{*}=4.6$ & & $\mathrm{a}^{*}=1.8$ & \\
& $\mathrm{~b}^{*}=21.4$ & & $\mathrm{~b}^{*}=50.9$ & \\
\hline \multirow{2}{*}{$200^{\circ} \mathrm{C}$} & $\mathrm{L}^{*}=26$ & & $\mathrm{~L}^{*}=56.9$ & \\
& $\mathrm{a}^{*}=7.5$ & & $\mathrm{a}^{*}=3.7$ & \\
\hline \multirow{2}{*}{$240^{\circ} \mathrm{C}$} & $\mathrm{b}^{*}=23.3$ & & $\mathrm{~b}^{*}=50.4$ & \\
& $\mathrm{~L}^{*}=24.8$ & & $\mathrm{~L}^{*}=56.7$ & \\
& $\mathrm{a}^{*}=9.2$ & & $\mathrm{a}^{*}=7$ & \\
& $\mathrm{~b}^{*}=22.8$ & & $\mathrm{~b}^{*}=50.2$ & \\
\hline
\end{tabular}

Fig. 9 Photographs at different temperature and CIE-Lab parameters of $\mathrm{Sm}_{3} \mathrm{Fe}_{5} \mathrm{O}_{12}$ with different particle size.

transitions is almost unchanged. This continuous red shift is due to the slightly expansion of ionic bonds with temperature increasing according to the lattice constant increase with the increasing of temperature. ${ }^{11}$ Unit-cell expansion causes a reduction of the electrostatic interaction of d electrons so the $\mathrm{O}^{2-} \rightarrow$ $\mathrm{Fe}^{3+}$ charge transfer requires lower energy. Tauc plots of the UVvis spectra and linear fitting of the energy bandgap dependent on temperature show bandgap energy is getting lower with increasing temperature, which means absorption peak shifts to long wavelength side as the temperature increases. This result correspond with the red-shift of UV-vis spectra.

Fig. 9 show the photographs of thermochromism and $L^{*} a b$ parameters for $\mathrm{Sm}_{3} \mathrm{Fe}_{5} \mathrm{O}_{12}$ with different particle size. Thermochromic behaviour of $\mathrm{Sm}_{3} \mathrm{Fe}_{5} \mathrm{O}_{12}$ was investigated from $40{ }^{\circ} \mathrm{C}$ to $240{ }^{\circ} \mathrm{C}$. From Fig. 9 the macroscopic thermochromic behaviour can be obviously observed in the range of $40-160^{\circ} \mathrm{C}$, but significant thermochromic phenomenon were not detected beyond $160{ }^{\circ} \mathrm{C}$. The color of $\mathrm{Sm}_{3} \mathrm{Fe}_{5} \mathrm{O}_{12}$ synthesized by solid state reaction method changed from blackish green to brown with the increasing of temperature, while $\mathrm{Sm}_{3} \mathrm{Fe}_{5} \mathrm{O}_{12}$ synthesized by solgel method changed from bright yellow green to yellow. The color at room temperature of $\mathrm{Sm}_{3} \mathrm{Fe}_{5} \mathrm{O}_{12}$ with different particle size originate from the combination of an $\mathrm{O}^{2-} \rightarrow \mathrm{Fe}^{3+}$ ligand-to-metal charge transfer at $2.54 \mathrm{eV}$ (solid state method), $2.76 \mathrm{eV}$ (sol-gel) and d-d transitions at 1.38 and $2.03 \mathrm{eV}^{10}$ The reason for caused the colour change is continuous red shift of the absorption bands associate with the expansion of ionic bonds with temperature increasing, which is proved by the increase of the lattice parameter with temperature. ${ }^{11}$ The electrostatic interaction of the d electrons reduced go along with the elongation of ionic bonds, which means the $\mathrm{d}^{6}$ energy level is in a lower position and the charge transfer required lower energy.

\section{Conclusions}

In conclusion, we used solid state reaction method and sol-gel method to synthesize $\mathrm{Sm}_{3} \mathrm{Fe}_{5} \mathrm{O}_{12}$ with different particle size, 
which display a significant color difference. $\mathrm{Sm}_{3} \mathrm{Fe}_{5} \mathrm{O}_{12}$ with different particle size were cubic crystallographic system with the space group of $I a \overline{3} d$ and lattice parameter increases with the decreases of particle size. The color difference originate from the increases of the bandgap with the decrease of the particle size, which lead to the absorption band shifts to shorter wavelength side and thereby the color of $\mathrm{Sm}_{3} \mathrm{Fe}_{5} \mathrm{O}_{12}$ with small particle size is brighter. The thermochromic phenomenon is attributed to the reduction of energy required for charge transfer with temperature increasing, resulting in continuous red shift of the absorption edge. The study means that the optical properties of thermochromic materials could be adjustable by optimizing the particle size.

\section{Acknowledgements}

This work was supported by the "Twelfth Five Year" Project (No. 2015-466) and "Thirteenth Five Year" Project (No. JJKH20170217KJ) of Science and Technology Research in the Education Department of Jilin Province and the Natural Science Fund of Jilin Provincial Science \& Technology Department (No. 20160101326JC).

\section{References}

1 E. Lataste, A. Demourgues, J. Salmi, C. Naporea and M. Gaudon, Dyes Pigm., 2011, 91, 396-403.

2 M. Gaudon, P. Deniard, L. Voisin, G. Lacombe, F. Darnat, A. Demourgues, J.-L. Perillon and S. Jobic, Dyes Pigm., 2012, 95, 344-350.

3 J. H. Day, Chem. Rev., 1968, 68, 649-657.

4 G. Salek, A. Demourgues, V. Jubera, A. Garcia and M. Gaudon, Opt. Mater., 2015, 47, 323-327.

5 A. Seeboth and D. Lötzsch, Thermochromic and Thermotropic Materials, Taylor \& Francis Group, 2013, ISBN-13: 978-9814411-03-5.

6 M. M. Seyfouri and R. Binions, Sol. Energy Mater. Sol. Cells, 2017, 159, 52-65.

7 R. Chen, L. Miao, H. L. Cheng, E. Nishibori, C. Y. Liu, T. Asaka, Y. Iwamoto, M. Takata and S. Tanemura, J. Mater. Chem. A, 2015, 3, 3726-3738.

8 M. Gaudon, P. Deniard, A. Demourgues, A.-E. Thiry, C. Carbonera, A. Le Nestour, A. Largeteau, J.-F. Létard and S. Jobic, Adv. Mater., 2007, 19, 3517-3519.

9 L. C. Robertson, M. Gaudon, S. Jobic, P. Deniard and A. Demourgues, Inorg. Chem., 2011, 50, 2878-2884.

10 H. Serier-Brault, L. Thibault, M. Legrain, P. Deniard, X. Rocquefelte, P. Leone, J.-L. Perillon, S. Le Bris, J. Waku and S. Jobic, Inorg. Chem., 2014, 53, 12378-12383.

11 H. Liu, L. Yuan, S. Wang, H. Fang, Y. Zhang, C. Hou and S. Feng, J. Mater. Chem. C, 2016, 4, 10529-10537.

12 Y. Yamasaki, Y. Kohara and Y. Tokura, Phys. Rev. B: Condens. Matter Mater. Phys., 2009, 80, 140412(R).

13 R. C. Lecraw, E. G. Spencer and C. S. Porter, Phys. Rev., 1958, 110, 1311-1313.

14 M. A. Gilleo and S. Geller, Phys. Rev., 1958, 110, 73-78.

15 S. Geller, J. Appl. Phys., 1960, 31, S30-S37.

16 R. Pauthenet, J. Appl. Phys., 1959, 30, S290-S292.
17 M. Deb, E. Popova, A. Fouchet and N. Keller, Phys. Rev. B: Condens. Matter Mater. Phys., 2013, 87, 224408.

18 L. Guo, K. Huang, Y. Chen, G. Li, L. Yuan, W. Peng, H. Yuan and S. Feng, J. Solid State Chem., 2011, 184, 1048-1053.

19 V. J. Fratello, C. D. Brandle, S. E. G. Slusky, A. J. Valentino, M. P. Norelli and R. Wolfe, J. Cryst. Growth, 1986, 75, 281-283.

20 T.-J. Park, G. C. Papaefthymiou, A. J. Viescas, A. R. Moodenbaugh and S. S. Wong, Nano Lett., 2007, 7, 766-772.

21 S. Q. Yin, T. Sauyet, M. S. Seehra and M. Jain, J. Appl. Phys., 2017, 121, 063902.

22 T. Chen, Y. W. Zhang and W. L. Xu, Phys. Chem. Chem. Phys., 2016, 18, 22494-22502.

23 X. Rozanska, R. Fortrie and J. Sauer, J. Am. Chem. Soc., 2014, 136, 7751-7761.

24 X. C. Zhou, W. L. Xu, G. K. Liu, D. Panda and P. Chen, J. Am. Chem. Soc., 2010, 132, 138-146.

25 J. Grottrup, V. Postica, N. Ababii, O. Lupan, C. Zamponi, D. Meyners, Y. K. Mishra, V. Sontea, I. Tiginyanu and R. Adelung, J. Alloys Compd., 2017, 701, 920-925.

26 C. C. Yang and Y.-W. Mai, Chem. Phys. Lett., 2012, 535, 91-93. 27 N. Venkatram, R. Sathyavathi and D. Narayana Rao, Opt. Express, 2007, 15, 12258-12263.

28 R. Viter, A. Katoch and S. S. Kim, Met. Mater. Int., 2014, 20, 163-167.

29 Y. Gupta, P. Arun, A. A. Naudi, M. V. Walz and E. A. Albanesi, Thin Solid Films, 2016, 612, 310-316.

30 H. Tamaki, H. Watanabe, S. Kamiyama, Y. Oaki and H. Imai, Angew. Chem., Int. Ed., 2014, 53, 10706-10709.

31 H. Liu, L. Yuan, H. Qi, S. Wang, Y. Du, Y. Zhang, C. Hou and S. Feng, Dyes Pigm., 2017, 145, 418-426.

32 I. Ahmada, T. Abbas, A. B. Ziya, G. Abbas and A. Maqsood, Mater. Res. Bull., 2014, 52, 11-14.

33 W. J. Duan, S. H. Lu, Z. L. Wu and Y. S. Wang, J. Phys. Chem. $C, 2012,116,26043-26051$.

34 A. Kumar and D. P. Ojha, Indian J. Phys., 2016, 90, 1041-1047. 35 P. B. A. Fechine, E. N. Silva, A. S. de Menezes, J. Derov, J. W. Stewart, A. J. Drehman, I. F. Vasconcelos, A. P. Ayala, L. P. Cardoso and A. S. B. Sombra, J. Phys. Chem. Solids, 2009, 70, 202-209.

36 I. V. Chernyshova, M. F. Hochella Jr and A. S. Madden, Phys. Chem. Chem. Phys., 2007, 9, 1736-1750.

37 K. Z. Zheng, W. Y. Song, C. J. Lv, Z. Y. Liu and W. P. Qin, CrystEngComm, 2014, 16, 4329-4337.

38 J. P. Hurrell, S. P. S. Porto, I. F. Chang, S. S. Mitra and R. P. Bauman, Phys. Rev., 1968, 173, 851-856.

39 L. Guo, H. Yuan, K. Huang, L. Yuan, S. Liu and S. Feng, Chem. Res. Chin. Univ., 2011, 27, 715-719.

40 M. Mullet, Y. Guillemin and C. Ruby, J. Solid State Chem., 2008, 181, 81-89.

41 C. Suchomski, C. Reitz, C. T. Sousa, J. P. Araujo and T. Brezesinski, Chem. Mater., 2013, 25, 2527-2537.

42 H. Qi, H. Liu, S. Wang, L. Yuan and C. Hou, Chem. J. Chin. Univ., 2017, 38, 535-540.

43 M.-S. Jang, I.-J. Roh, J. Park, C.-Y. Kang, W. J. Choi, S.-H. Baek, S. S. Park, J.-W. Yoo and K.-S. Lee, J. Alloys Compd., 2017, 711, 693-697. 